\title{
Studies on some Garlic Diseases during Storage in Egypt
}

\author{
El-Marzoky, Hanan A. and W. I. Shaban \\ Agricultural Botany Department, Faculty of Agriculture, Suez Canal University, Ismailia, Egypt
}

Received: $1 / 3 / 2014$

\begin{abstract}
Garlic (Allium sativum L.) is one of the more popular cultivated Alliums and many fungal pathogens causing postharvest disease under humid and warm storage conditions. Botrytis allii, Aspergillus niger and Fusarium solani were capable of causing severe rots to cloves of Balady and Chinese garlic cultivars after harvest and during storage. However, Penicillium chrysogenum, Cladosporium sp., Stemphylium botrysum, Helminthosporium allii, Alternaria tenuis and Sclerotium cepivorum were less virulent on both cultivars. Immature and mature garlic bulbs of the two cultivars greatly differed in their reactions to the three fungi. The immature bulbs of both cultivars were the most susceptible to $B$. allii, $A$. niger and $F$. solani, while the mature bulbs were less infected. In the same time, the percentage of dry cloves and loose bulbs were higher in immature bulbs compared with mature bulbs, either inoculated artificially or left for natural infection. In contrast, the mature bulbs showed lower percentages of depletion (waxy brake down), loose bulbs and pathological decay. Higher percentages of healthy bulbs were observed in perforated craft paper, followed by plastic nets and perforated polyethylene bags. Garlic rots were higher in immature bulbs than that in mature ones of un-inoculated bulbs of Balady and Chinese cultivars during storage for 150 days at $25^{\circ} \mathrm{C}$ and $10^{\circ} \mathrm{C}$. Dipping the basal parts of garlic bulbs in $1000 \mathrm{ppm}$ of Thiabendazole (TBZ) in soluble wax were effective in decreasing percentages of rots in bulbs artificially inoculated with each of $B$. allii, F. solani and A. niger or left for natural infection. Moreover, treatment with TBZ showed best protective effect against looseness in all treated bulbs.
\end{abstract}

Keywords: Pathological decay, immature, cultivar reactions, depletion, dry rot, Thiabendazole, loose bulbs.

\section{INTRODUCTION}

Garlic (Allium sativum L.) is the most important commercial crops grown all over the world and consumed in various forms. It is also known to lower blood sugar and cholesterol levels. Its many other health-promoting attributes have been resulted in medicinal pills, drinks and powders based on garlic extracts. Quality of the crop is very important requirement especially for exportation. Numerous fungi attack garlic cloves during storage resulting in decay causing considerable losses and decreasing the quality. In Egypt, Kararah and El-Tobshy (1979) found a degree of resistance in Chinese cultivar to $F$. solani than in Balady one. Radwan (1980) reported that severity of infection increased in immature Balady garlic cloves inoculated with $F$. oxysporum or Penicillium chrysogenum compared with mature and over-mature cloves when stored from 30 to 150 days at $25^{\circ} \mathrm{C}$. Garlic bulbs are susceptible to Fusarium, Penicillium and Botrytis rots, particularly if bulbs are damaged. Many postharvest pathogens of garlic may be carried in seed cloves (Schwartz and Mohan, 2006 and Dugan et.al. 2007). In this regard, Ghangaonkar (2013) noted that Aspergillus niger, Fusarium oxysporum, Macrophomina Phaseolina, Botrytis alli, Penicillium corymbiferum, Aspergillus flavus, Rhizopus stolonifer, Chaetomium globosum are specially found on bulbs from storage. The present investigation was carried out to study the effect of harvesting at two different maturity stages on susceptibility of garlic bulbs artificially inoculated with three fungi or left for natural infection during storage. Evaluation of different types of containers on the keeping quality of garlic during storage, effect of storage temperature on garlic rots and effect of fungicidal treatment on the incidence of garlic rots were also studied.

\section{MATERIALS AND METHODS}

Isolation and identification of associated fungi

Diseased garlic bulbs were collected in polyethylene bags from retail and whole sale markets as well as storage places from different areas of Ismailia Governorate. These samples were either used immediately or stored at $5 \pm 2^{\circ} \mathrm{C}$ in the laboratory for different pathological studies. The cloves were surface sterilized with $70 \%$ ethyl alcohol for one min, followed by washing in sterile distilled water. The outer coat was removed and the internal diseased portions were transferred to PDA medium in Petri dishes. Plates were incubated at $25 \pm 2^{\circ} \mathrm{C}$ for seven days. The isolated pathogens were identified on the basis of morphological and cultural characteristics according to Raper and Fennell (1965), Booth (1971) Barnett and Hunter (1999) and Eltem et al. (2004).

Reactions of Balady and Chinese garlic cultivars to the isolated fungi

Cloves of Balady and Chinese garlic cultivars were inoculated with the isolated fungi A. niger, B. allii or $F$. solani through artificial wounds near the apex of the cloves with $5 \mathrm{ml}$ of spore suspension $\left(2.5 \times 10^{5}\right.$ spores $/ \mathrm{ml}^{3}$ )as adopted by Muimba et al. (1983). Inoculated and non-inoculated cloves of the two tested cultivars were incubated at $25 \pm 2^{\circ} \mathrm{C}$ for 10,20 , and 30 days. Twenty five cloves were used for each fungal and control treatments. Decay amount was estimated as a percentage of decayed bulbs or cloves for each treatment.

\section{Maturity stage (Physiological age}

Garlic plants, grown in one field and receiving uniform production treatments, at Ismailia Governorate, were harvested at two different maturity stages ( 6 and 7 months old during March and April 2011). After harvesting, garlic plants were bunched, and then left 15 
days in open air for curing. Garlic bulbs of each maturity stage were carefully selected free from mechanical injury or diseases. Under aseptic conditions, garlic bulbs were inoculated with the fungal pathogen (A. niger, B. allii or F. solani) through wounds near the basal part of the bulbs as mentioned before. Another set of bulbs was left for natural infection. Bulbs were stored in jute sacks for 5 months and evaluated for qualitative and quantitative losses.

\section{Consumer containers (packages)}

Different containers, i.e., perforated or nonperforated small polyethylene bags, craft paper and plastic nets were used for packing garlic bulbs. Four replicates were used for each treatment with or without fungal infection and $2 \mathrm{kgm}$ garlic bulbs (about 25 bulbs, Balady garlic cv.) for each replicate were used. Bulbs were stored in different container types for 5 months at room temperature and evaluated for qualitative and quantitative losses.

\section{Effect of storage temperature on garlic rots}

Immature and mature bulbs of Balady and Chinese garlic cvs. were selected free from any mechanical injuries. Bulbs were inoculated separately with each of the three pathogens understudy with spore suspension as described previous. Another set of garlic bulbs were used without fungal injection for used as a control treatment. Inoculated and non-inoculated bulbs were incubated at $10 \pm 2$ and $25 \pm 2{ }^{\circ} \mathrm{C}$. Percentages of decayed bulbs were measured at 150 days after inoculation.

\section{Chemical control}

The basal part of the bulbs were artificially inoculated with each of the tested fungi at spore suspension or left for natural infection for used as a control treatment. The basal parts only of the bulbs near the root were dipped in $1000 \mathrm{ppm}$ Thiabendazole solution in soluble wax for 30 second, 24 hours after inoculation. The waxed bulbs were allowed to dry in the air and stored at $25 \pm 2^{\circ} \mathrm{C}$ for 5 months beginning May, 2011.

\section{RESULTS AND DISCUSSION}

\section{Isolation and identification of associated fungi}

Fungal pathogens isolated from collected garlic bulbs as well as their percentage of occurrence were recorded. It is obviously clear from table (1) Isolation from collected garlic bulb decay yielded the associated of one or more of the following fungi, Fusarium solani, Botrytis allii and Aspergillus niger were the most common fungi associated with rotted garlic cloves. Whereas, Penicillium chrysogenum, Stemphylium botrysum, Cladosporium sp., Alternaria tenuis, Helminthosporium allii and Sclerotium cepivorum occurred in less frequency of total counts of fungal colonies isolated from rotted garlic cloves. The isolated fungi were also reported as garlic rotted pathogens such as Abdel-Al et al. (1991), Koch and Taanami (1995), Dugan et al. (2003) and Schwartz and Krishna Mohan (2006).

Reactions of Balady and Chinese garlic cultivars to the isolated fungi

Data presented in table (2) indicate that the highest percentage of rotted cloves was recorded on Balady cloves inoculated with $A$. niger followed by $B$. allii and $F$. solani. In the same time, Chinese cv. showed higher percentage in rotted cloves with $B$. allii followed by $F$. solani. Whereas, the lowest percentage of rotted cloves was observed in Chinese cv. inoculated with $A$. niger at 30 days after incubation at $25 \pm 2{ }^{\circ} \mathrm{C}$. Similar results were observed by Abdel-Al et al. (1991), Sumner (1995) and Dugan et al. (2007).

\section{Maturity stage (Physiological age)}

It is clear from Table (3) that immature and mature garlic bulb were differed in their reactions to the three tested fungi. The immature bulbs were the most susceptible to B. allii, A. niger and F. solani, while the mature bulbs were less susceptible. Botrytis allii and $A$. niger showed significant pathological losses and total losses followed by $F$. solani compared to the control treatments. At the same time, $F$. solani showed the significant mechanical losses and reduction in healthy bulbs on mature or immature garlic bulbs followed by Botrytis allii and A. niger pathogens. On the other hand, some physiological losses were increased in immature bulb than in immature bulb. In this regard, the percentage of total loose and loose bulbs were higher in immature bulbs compared with mature bulbs, either inoculated artificially or left for natural infection. In contrast, the mature bulbs showed lower percentages of depletion (waxy brake down), loose bulbs and pathological decay. Our observations and results were concurrent with these previously described indicators of the different stages of maturity with those Grieve (2006) and Kamenetsky (2007).

Table (1): Frequency of the isolated fungi from Balady and Chinese garlic cloves (Balady and Chinese cvs.)

\begin{tabular}{lcc}
\hline \multicolumn{1}{c}{ Isolated fungi } & \multicolumn{2}{c}{ Garlic cultivars } \\
\cline { 2 - 3 } & Balady & Chinese \\
\hline Aspergillus niger & 64.4 & 45.6 \\
Botrytis allii & 59.3 & 34.3 \\
Fusarium solani & 55.5 & 47.8 \\
Penicillium chrysogenum & 48.2 & 31.4 \\
Alernaria tenuis & 37.2 & 14.5 \\
Cladosporium sp. & 34.0 & 19.2 \\
Helminthosporium allii & 26.3 & 21.6 \\
Stemphylium botryosum & 14.4 & 17.5 \\
Sclerotium cepivorum & 4.0 & 2.1 \\
\hline
\end{tabular}


Table (2): Reactions of Balady and Chinese garlic cultivars on garlic bul decay caused by Aspergillus nige, Botrytis allii and Fusarium solani

\begin{tabular}{ccc}
\hline \multirow{2}{*}{ Garlic Cultivars } & \multicolumn{2}{c}{ Artificial inoculation and disease severity \% } \\
\cline { 2 - 3 } & Balady & Chinese \\
\hline Aspergillus niger & 53.3 & 28.2 \\
Botrytis allii & 47.5 & 42.6 \\
Fusarium solani & 34.7 & 35.1 \\
Control & 1.7 & 1.3 \\
LSD at 5\% & 3.7 & 4.5 \\
\hline
\end{tabular}

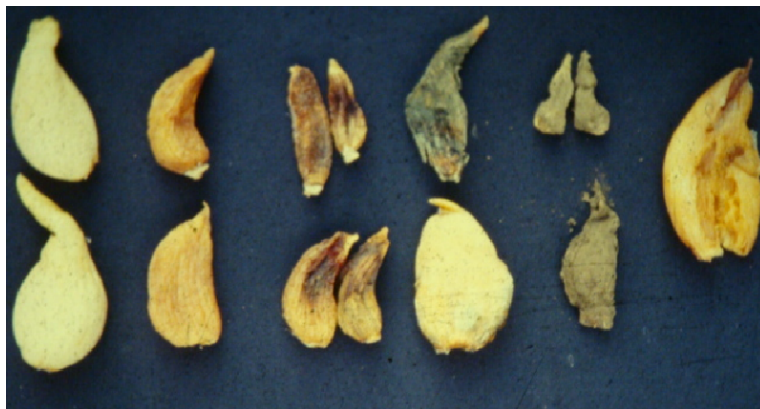

(A)
(B)
(C)

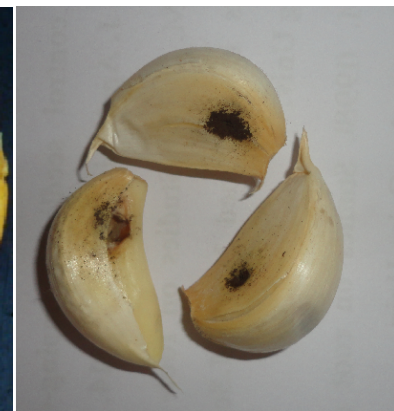

(G)

Figure (1): Symptoms of storage rotted cloves ; Healthy cloves (A); depletion (waxy brake down) dry cloves (B); Fusarium solani, discolored dry rot (C); Penicillium chrysogenum, green-blue color (D); Botrytis allii, gray mould (E); Erwenia carotovera, Bacterial soft rot (F), Aspergillus niger black mould (G).

Table (3): Effect of storage mature and immature garlic bulbs, 5 months after inoculation with three fungi or left without inoculation on percentage of infection.

\begin{tabular}{|c|c|c|c|c|c|c|c|c|c|c|c|c|}
\hline \multirow{3}{*}{$\begin{array}{c}\text { Fungal } \\
\text { treatments }\end{array}$} & \multicolumn{12}{|c|}{ Percentage of infection on garlic bulb losses } \\
\hline & \multicolumn{2}{|c|}{$\begin{array}{l}\text { Pathological } \\
\text { losses }\end{array}$} & \multicolumn{2}{|c|}{ Depletion } & \multicolumn{2}{|c|}{ Loose bulbs } & \multicolumn{2}{|c|}{$\begin{array}{l}\text { Mechanical } \\
\text { losses }\end{array}$} & \multicolumn{2}{|c|}{ Total losses } & \multicolumn{2}{|c|}{$\begin{array}{c}\text { Healthy } \\
\text { bulbs }\end{array}$} \\
\hline & I & $\mathbf{M}$ & I & $\mathbf{M}$ & I & $\mathbf{M}$ & I & M & I & M & I & $\mathbf{M}$ \\
\hline B. allii & 45.6 & 38.5 & 28.2 & 19.5 & 2.9 & 2.2 & 3.5 & 3.5 & 79.5 & 64.4 & 20.5 & 35.6 \\
\hline F. solani & 41.5 & 37.2 & 20.7 & 16.4 & 1.9 & 1 & 4.1 & 4 & 68.2 & 61.3 & 31.8 & 38.7 \\
\hline A. niger & 45.5 & 37 & 25.1 & 20.9 & 2.3 & 1.8 & 3.1 & 3.4 & 75.8 & 52.6 & 24.2 & 47.4 \\
\hline $\begin{array}{c}\text { Without } \\
\text { inoculation }\end{array}$ & 16.2 & 7.8 & 18.1 & 11.6 & 2.3 & 1.9 & 1.4 & 1.1 & 33.3 & 22.7 & 66.7 & 76.6 \\
\hline L S D 5\% & 2.21 & 1.63 & 2.67 & 1.78 & 0.85 & 1.19 & 1.13 & 0.73 & 1.34 & 1.71 & 2.41 & 2.53 \\
\hline
\end{tabular}

The average percentage of healthy bulbs, 5 months after storage reached 66.7 and 77.6 for immature and mature bulbs, left for natural infection, respectively. In general, the immature garlic bulbs were significantly susceptible to the three pathogenic fungi compared with the control, while the mature bulbs were less infected. The obtained results show clearly the effect of maturity degrees on susceptibility of garlic bulbs to fungal infection, depletion and loose bulbs during storage. The extension of the rot and rate of development was greater in most cases in immature than in mature inoculated bulbs. This could be attributed to higher moisture content in plants harvested earlier which favors greatly the fungal growth and infection. Therefore, it could be concluded that percentage of rot increased in immature garlic bulbs. These results are in agreement with those reported by Radwan (1980) and Dugan et al. (2007). For utility reasons, the stage at which garlic is harvested is necessarily a compromise between yield, storage life and quality (Brecht, 2003; Grieve, 2006; Dhatt and Mahajan, 2007 and Bachmann and Hinman, 2008).

\section{Consumer containers (packages)}

Effect of perforated or none perforated of craftpaper bags, polyethylene bags and plastic net on garlic bulb decay was carried out in this trial. According our results, Botrytis allii caused significant pathological losses on garlic bulb compared with those inoculated with $F$. solani and $A$. niger as well as natural infection (Table 4). The highest significant losses were recorded in bulbs inoculated with $B$. allii and placed in nonperforated polyethylene bags $(90.7 \%)$ followed by bulbs inoculated with $A$. niger $(66.7 \%)$ and F. solani $(65.3 \%)$ packed in the same type of package, respectively. In the same time, percentage of losses in non-inoculated bulbs in this bag reached $(52.9 \%)$. Increase in percentage of 
fungus infected bulbs in non-perforated bags may be due to the condensation of moisture in this type of bags which encourage fungus spores germination, infection and further development during storage.

Higher percentages of healthy bulbs were observed in perforated craft paper, followed by plastic nets and perforated polyethylene bags which could be due to higher ventilation. Perforated craft-paper bags resulted in the most suitable storage conditions. In addition, it was observed that packing large size of garlic bulbs results in higher percentages of decay in each of tested package compared with medium and small size of bulbs (data not shown). It can be concluded, in general, plastic net was showed less percentage in garlic losses followed by perforated bags with different tested pathogens. In addition, packing garlic bulbs in perforated craft-paper (about $2 \mathrm{kgm}$ ) as a consumer package resulted in lower percentage of rotted bulbs and improved garlic quantity and quality.

\section{Effect of storage temperature on garlic rots}

Data presented in Table (5) indicate that storage immature Balady cv. bulbs at $10 \pm 2^{\circ} \mathrm{C}$ became highly susceptible to $B$. allii compared with mature bulbs of the same cultivar at $25 \pm 2^{\circ} \mathrm{C}$. In the contrary, storage garlic bulb at $10 \pm 2^{\circ} \mathrm{C}$ showed increasing in percentage of infected bulb compared with storage condition at $25 \pm 2{ }^{\circ} \mathrm{C}$. Chinese cv. exhibited a higher percentage of infection in immature bulbs inoculated with each of the three fungi at $10 \pm 2^{\circ} \mathrm{C}$ and $25 \pm 2^{\circ} \mathrm{C}$, however, mature bulbs recorded the lowest percentage of decay at all 5 months storage at the both degrees. It is clear that garlic rots were higher in immature bulbs than that in mature ones of un-inoculated bulbs of Balady and Chinese cultivars during storage for 5 months at $10 \pm 2^{\circ} \mathrm{C}$ and $25 \pm 2^{\circ} \mathrm{C}$. Bulbs recorded the highest reduction in garlic rot and maximum loss caused by tested fungi during storage at $25 \pm 2^{\circ} \mathrm{C}$ followed by those stored at $10 \pm 2^{\circ} \mathrm{C}$.
Similar results were obtained by Smalley and Hansen (1962) who reported that garlic stored at $5^{\circ} \mathrm{C}$ before inoculation with Penicillium corymbiferm was less susceptible than stored at $25^{\circ} \mathrm{C}$. These results are also in agreement with those reported by Kararah and ElTobshy (1979) as they found that $40^{\circ} \mathrm{C}$ exhibited the maximum decrease in weight of intact cloves of Balady and Chinese cvs. However, stored cloves at room temperature recorded the highest reduction in weight followed by cloves stored at $10^{\circ} \mathrm{C}$. Also, this findings are in agreement with those of Ko et al. (2002) who considered disease severity, both in lesion size and sporulation degree, increased with higher inoculum densities and incubation temperatures.

\section{Chemical control}

Dipping the basal parts of garlic bulbs in $1000 \mathrm{ppm}$ of Thiabendazole (TBZ) in soluble wax were effective in decreasing percentages of rots in artificially inoculated garlic bulbs with each of $B$. allii, F. solani and $A$. niger or left for natural infection (Table 6). It is clear that $A$. niger was more affected by TBZ treatment specially in controlling the pathological losses and in total losses when compared with $B$. allii and $F$. solani. The highest percentage of healthy bulbs was recorded in treated bulbs with TBZ in soluble wax and left for natural infection for 5 months storage. Moreover, fungicide treatment showed best protective effect against looseness in all treated bulbs, either artificially inoculated or left for natural infection. It could be concluded that this treatment can be successfully used to prevent infections and suppress the development of garlic rots during storage. In addition, this treatment recorded the best protection against looseness in bulbs and improves garlic quality. Prevention and control of some post harvest fungal diseases of garlic bulbs was reported by Gargi (1988) and Abdel-Al et.al. (1991) and Wani and Taskeen (2011).
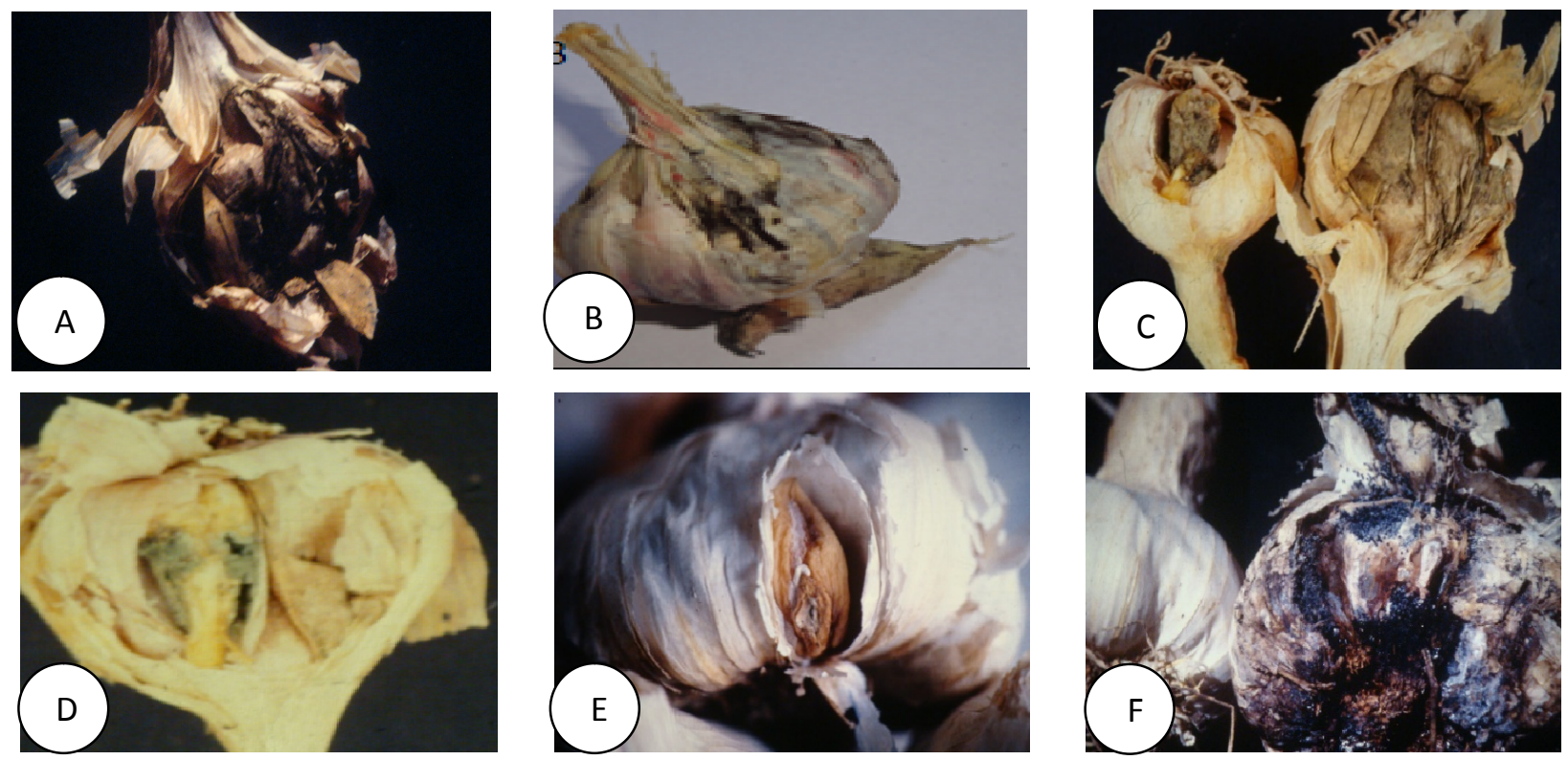

Figure (2): Decayed garlic bulb(A), Black mould from which Aspergillius niger was isolated (B) Symptoms of gray mould caused by Botrytis allii (C), Pinicilium rot (D), and Fusarium dry rot from which Fusarium solani was isolated (E) and Sclerotia of Sclerotium cepivorum (F), 150 days after storage at $20-25^{\circ} \mathrm{C}$. 
Table (4): Percentages of postharvest losses in garlic bulbs with and without artificial inoculation during storage as affected by different types of consumer containers.

\begin{tabular}{|c|c|c|c|c|c|c|c|c|c|c|c|c|c|c|c|c|c|c|c|c|}
\hline \multirow{4}{*}{$\begin{array}{l}\text { Fungal } \\
\text { treatments }\end{array}$} & \multicolumn{20}{|c|}{ Percentage of post harvest losses } \\
\hline & \multicolumn{5}{|c|}{ Pathological losses } & \multicolumn{5}{|c|}{ Depletion } & \multicolumn{5}{|c|}{ Total losses } & \multicolumn{5}{|c|}{ Healthy } \\
\hline & \multicolumn{2}{|c|}{$\begin{array}{l}\text { Poly } \\
\text { ethylene } \\
\text { Bags }\end{array}$} & \multicolumn{2}{|c|}{ Paper bags } & \multirow[t]{2}{*}{$\begin{array}{l}\text { Plastic } \\
\text { nets }\end{array}$} & \multicolumn{2}{|c|}{$\begin{array}{l}\text { Poly ethylene } \\
\text { Bags }\end{array}$} & \multicolumn{2}{|c|}{ Paper bags } & \multirow[t]{2}{*}{$\begin{array}{l}\text { Plastic } \\
\text { nets }\end{array}$} & \multicolumn{2}{|c|}{$\begin{array}{l}\text { Poly } \\
\text { ethylene } \\
\text { Bags }\end{array}$} & \multicolumn{2}{|c|}{ Paper bags } & \multirow[t]{2}{*}{$\begin{array}{l}\text { Plastic } \\
\text { nets }\end{array}$} & \multicolumn{2}{|c|}{$\begin{array}{l}\text { Poly } \\
\text { ethylene } \\
\text { Bags }\end{array}$} & \multicolumn{2}{|c|}{ Paper bags } & \multirow[t]{2}{*}{$\begin{array}{l}\text { Plastic } \\
\text { nets }\end{array}$} \\
\hline & $\mathrm{P}$ & $\mathrm{NP}$ & $\mathrm{P}$ & $\mathrm{NP}$ & & $\mathrm{P}$ & $\mathrm{NP}$ & $\mathrm{P}$ & $\mathrm{NP}$ & & $\mathrm{P}$ & $\mathrm{NP}$ & $\mathrm{P}$ & $\mathrm{NP}$ & & $\mathrm{P}$ & $\mathrm{NP}$ & $\mathrm{P}$ & $\mathrm{NP}$ & \\
\hline Botrytis allii. & 38.9 & 59.7 & 40.8 & 53.4 & 33.3 & 35.5 & 31 & 21.5 & 21.1 & 20.2 & 74.4 & 90.7 & 62.6 & 73.8 & 58.4 & 5.6 & 9.3 & 37.7 & 25.2 & 11.6 \\
\hline Fusarium solani & 32.1 & 45.8 & 31.2 & 36.4 & 30.1 & 20.2 & 19.1 & 24.2 & 20.9 & 18.4 & 53.3 & 65.3 & 54.4 & 57.3 & 50.5 & 47.7 & 34.7 & 45.6 & 42.7 & 23.5 \\
\hline Aspergillus niger & 36.3 & 44.8 & 32.2 & 36.1 & 26.5 & 25.1 & 21.4 & 24.9 & 25.2 & 24.7 & 61.4 & 66.7 & 57.1 & 61.3 & 52.2 & 38.6 & 33.3 & 42.9 & 38.7 & 27.8 \\
\hline $\begin{array}{l}\text { Natural } \\
\text { infection }\end{array}$ & 8.6 & 32.1 & 6.4 & 17.4 & 7.9 & 21.3 & 20.8 & 20.2 & 27.3 & 19.9 & 29.9 & 52.9 & 26.6 & 44.7 & 20.8 & 70.1 & 47.1 & 73.4 & 55.3 & 32.2 \\
\hline LSD 5\% & 2.41 & 1.49 & 1.91 & 6.3 & 1.76 & 1.96 & 1.56 & 1.69 & 4.57 & 1.84 & 1.66 & 1.88 & 1.69 & 1.90 & 2.01 & 1.83 & 2.38 & 1.82 & 1.91 & 1.88 \\
\hline
\end{tabular}

Table (5): Effect of storage temperature on garlic rots of mature and immature garlic bulbs inoculated with each of the three fungi, incubated at 10 and $25^{\circ} \mathrm{C}$ for 150 days on the infection percentage.

\begin{tabular}{lcccccccc}
\hline & \multicolumn{6}{c}{ Infection \% of garlic rot of two cultivar at 10 and 25 oC } \\
\cline { 2 - 9 } Inoculated fungi & \multicolumn{3}{c}{ Balady } & \multicolumn{5}{c}{ Chinese } \\
\cline { 2 - 9 } & \multicolumn{2}{c}{ Immature } & \multicolumn{2}{c}{ Mature } & \multicolumn{2}{c}{ Immature } & Mature \\
\cline { 2 - 9 } & $\mathbf{1 0}^{\mathbf{0}} \mathbf{C}$ & $\mathbf{2 5}^{\mathbf{0}} \mathbf{C}$ & $\mathbf{1 0}^{\mathbf{0}} \mathbf{C}$ & $\mathbf{2 5}^{\mathbf{0}} \mathbf{C}$ & $\mathbf{1 0}^{\mathbf{0}} \mathbf{C}$ & $\mathbf{2 5}^{\mathbf{0}} \mathbf{C}$ & $\mathbf{1 0}^{\mathbf{0}} \mathbf{C}$ & $\mathbf{2 5}^{\mathbf{0}} \mathbf{C}$ \\
\hline Fusarium solani & 32.1 & 35.2 & 22.5 & 24.1 & 28.2 & 31.3 & 15.7 & 17.8 \\
Botrytis allii & 34.5 & 35.9 & 29.2 & 32.4 & 25.8 & 28.3 & 12.6 & 15.3 \\
Aspergillus niger & 27.3 & 29.6 & 24.9 & 26.5 & 27.1 & 29.3 & 13.5 & 15.2 \\
Naturally infected & 12.3 & 19.2 & 8.8 & 13.4 & 11.8 & 17.2 & 8.7 & 10.4 \\
(Control) & 2.1 & 1.5 & 2.4 & 1.8 & 1.4 & 2.2 & 1.3 & 1.2 \\
L S D 5\% & & & & & & &
\end{tabular}

Table (6): Percentage of post harvest losses in garlic bulbs inoculated with three fungi or left for natural infection and treated with 1000ppm Thiabendazole in soluble wax, stored for 5 months.

\begin{tabular}{ccccccccccc}
\hline \multirow{2}{*}{$\begin{array}{c}\text { Fungal } \\
\text { treatments }\end{array}$} & \multicolumn{8}{c}{ Percentage of post harvest losses } \\
\cline { 2 - 11 } & Pathological losses & \multicolumn{2}{c}{ Depletion } & \multicolumn{1}{c}{ Loose } & bulbs & \multicolumn{2}{c}{ Total losses } & \multicolumn{2}{c}{ Healthy bulbs } \\
\hline & $\mathrm{T}$ & $\mathbf{U}$ & $\mathbf{T}$ & $\mathbf{U}$ & $\mathbf{T}$ & $\mathbf{U}$ & $\mathbf{T}$ & $\mathbf{U}$ & $\mathbf{T}$ & $\mathbf{U}$ \\
\hline B. allii & 7.2 & 40.1 & 10.3 & 19.9 & 0 & 2.2 & 17.5 & 62.2 & 82.5 & 37.8 \\
$\boldsymbol{F}$. solani & 6.3 & 38.2 & 9.1 & 21.7 & 0 & 1.5 & 25.4 & 61.4 & 74.6 & 38.6 \\
$\begin{array}{c}\text { A. niger } \\
\text { Without }\end{array}$ & 3.3 & 38.2 & 10.6 & 20.5 & 0 & 1.7 & 13.9 & 60.4 & 86.1 & 39.6 \\
inoculation & 2.2 & 7.9 & 7.5 & 13.4 & 0 & 1.9 & 9.7 & 23.2 & 90.3 & 76.8 \\
L S D 5\% & 1.88 & 1.72 & 1.98 & 1.88 & 0.0 & 1.68 & 1.89 & 1.79 & 2.11 & 1.91 \\
\hline
\end{tabular}

$\mathbf{T}=$ Treated, $\quad \mathbf{U}=$ Untreated

\section{REFERENCES}

Abdel-Al, H.R., Baraka, M.A., El-Tobshy, Zeinab M. and El-Boghdady, M.M. (1991). Integrated control of postharvest garlic rot diseases. Egyptian Journal of Agricultural Research, 69:723-734.

Bachmann, J. and T. Hinman. (2008). Garlic: organic production.attra.ncat.org/attra-pub/PDF/ garlic.pdf.

Barnett, H.L. and Hunter, B.B. (1999). Illustrated Genera of Imperfect Fungi. The Amer.
Phytopathol. Soc. St. Paul, Minnesota (USA): Aps Pres.

Booth, C. (1971). The genus Fusarium.CMI, Kew. Surray. England. 237 pp.

Brecht, J. K. (2003). Underground storage organs. p. 625-647. In: J. A. Bartz and J. K. Brechet. Postharvest physiology and pathology of vegetable crops, II. Marcel Dekker Inc. NY.

Dhatt, A. S. and B. V. C., Mahajan (2007). Postharvest technology: havesting, handling and storage of horticultural crops. Punjab Hort. Postharv. 
Technol. Centre. Punjab Agricultural University Campus. Ludhiana. pp. 1-30.

Dugan, F.M., Hellier, B. C. and Lupien, S. L. (2003). First report of Fusarium proliferatum causing rot of garlic bulbs in North America. Plant Pathology, 52:426.

Dugan, F .M. Hellier, B. C. and Lupien, S. L. (2007). Pathogenic fungi in garlicseed cloves from the United State and China, and efficacy of fungicides against pathogens in garlic germplasm in Washington State. J. Phytopathol. 155:437 445.

Eltem, R., Abkun, T., SarÝg 1.N., Zkale, E. and Efendiler, H.( 2004). Colonial and Morphological characteristics of some Aspergillus Fr.:Fr. species isolated from vineyards in Manisa and Üzmir provinces (Turkey). Turk J. Bot. 28: 287-298.

Gargi , A. and Roy, N. (1988). Prevention and control of some post harvest fungal diseases of garlic bulbs .Pesticides 22:11-15.

Ghangaonkar N.M. (2013). Incidence of Mycoflora on Garlic (Allium Sativum L.) Bulbs. Int. Res. J. Biological Sci. 2: 64-66.

Grieve, M. (2006). Garlic. www.botanical.com/ botanical/ mgmh/g/garlic06.html.

Kamenetsky, R. 2007. Garlic: botany and horticulture. 33:123-172. In: J. Janick (eds). Hort. Rev. John Wiley and Sons, Inc.

Kararah, M. A., and El-Tobshy, Zieneb (1979). Preliminary observations on the effect of certain phytopathogenic organisms of garlic depletion phenomenon. $3^{\text {rd }}$ Egypt. Phytopathol, Congress. Pp. 419-443.
Ko, S.S; Huang, J.W., Wang, J.F., Shanmugasundaram, S. and Chang, W.N. (2002). Evaluation of onion cultivars for resistance to Aspergillus niger, the causal agent of black mould J. Amer. Soc. Hort. Sci., 127: 697-702.

Koch, M. and Taanami, Z. (1995). Occurrence of Fusarium rot of stored garlic in Israel. Plant Disease, 79:426.

Muimba, K. A., Addeniya, M .O and Terry, S. (1983). Suseptibility of cassava to Colletotrichum manihotis. In: Tropical root crops: Production and used in Africa. Proceed. $2^{\text {nd }}$ triannual symp. Int. Soc. for Tropical root crops, Africa brand, August, 1983, Douale, Cameron, 82-85.

Radwan, I. A. (1980). Studies on storage diseases of garlic in A.R.E., Ph.D. Thesis, Fac. Agric., Zagazig University. pp. 120.

Raper, K.B. and Fennell, D.I. (1965). The Genus Aspergillus, Baltimore: Williams \& Wilkins Company. pp 686.

Schwartz, H.F. and Krishna M. 2006. Compendium of onion and garlic diseases and pests, $2^{\text {nd }}$ Ed. APS Press.

Smalley, E. B. and Hansen, H. N. (1962). Penicillium decay of garlic. Phytopathology, 52:666-678.

Summer, D. R. 1995. Disease of bulbs caused by fungiblack mould, P. 26-27. In : H.F. Schwartz and S.K. Mohan, (eds). Compondium of onion and garlic disease. APS press, St. Paul, Minn

Wani A.H. and Taskeen-Un-Nisa. (2011). Management of black mould rot of onion Mycopath., 9: 43-49.

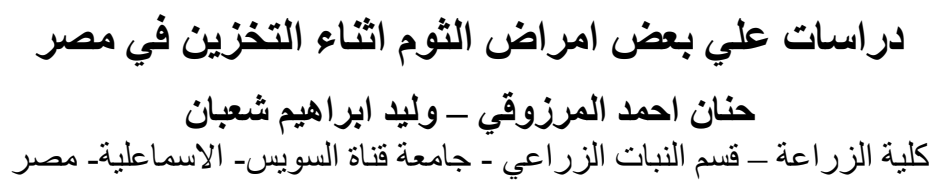

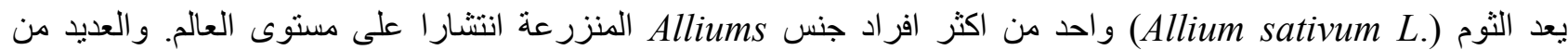

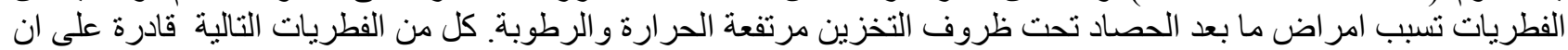

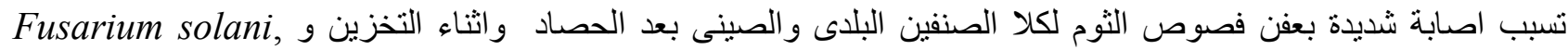
Penicillium chrysogenum, بينما اظهرت كل من الفطريات الاتية Botrytis allii, Aspergillus niger Cladosporium sp., Stemphylium botrysum, Helminthosporium allii, Alternaria tenuis and Sclerotium cepivorum

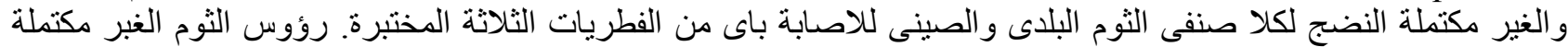

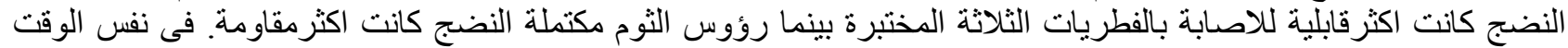

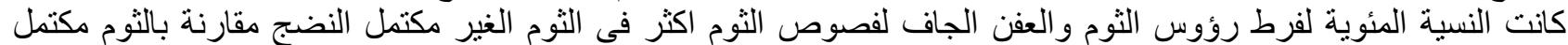

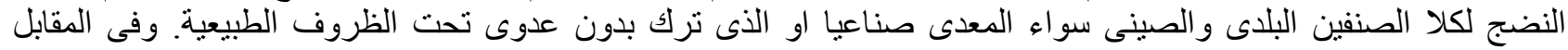

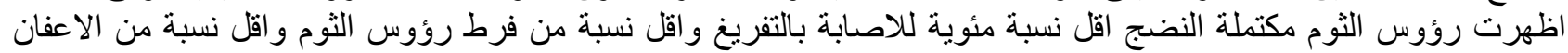

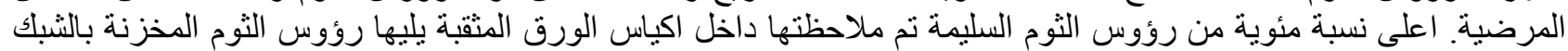

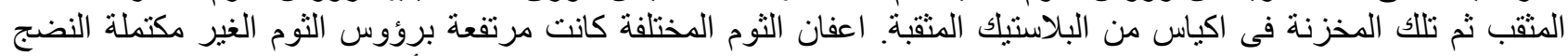

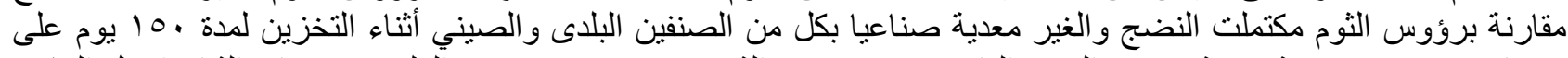

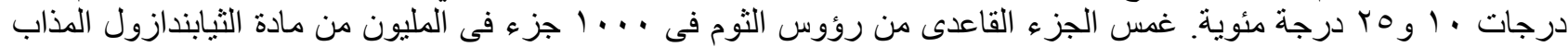

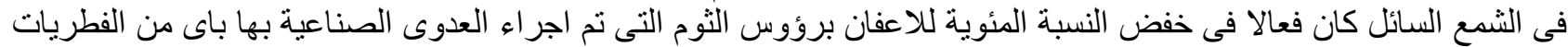
الثلاثة او نركت تحت ظروف العدان فعالافى الطبييعية. 